\title{
Primary and Metastatic Malignant Melanomas of the Digestive System
}

\section{Sindirim Sistemi Primer ve Metastatik Malign Melanomları}

Ozgur Kulahci ${ }^{1}$

Gulay Turan²,

${ }^{1}$ University of Health Sciences, Adana City Education and Research Hospital, Department of Pathology, Adana, Turkey ${ }^{2}$ Balıkesir University, School of Medicine, Department of Pathology, Balıkesir, Turkey

Geliş Tarihi/Received: 20 April 2020 Kabul Tarihi/Accepted: 29 June 2020

Address correspondence to: Ozgur Kulahci, University of Health Sciences, Adana City Education and Research Hospital, Department of Pathology, Adana, Turkey

e-mail:ozgurkulahci@hotmail.com

\section{ORCID}

Ozgur Kulahci

https://orcid.org/0000-0002-6636-1840 Gulay Turan

https://orcid.org//0000-0002-3702-8811

\begin{abstract}
Öz
Amaç: Primer ve metastatik sindirim sistemi malign melanomları oldukça nadirdir. Çalışmamızda safra kesesi, mide, ince bağırsak ve anorektal bölge malign melanomlarında lenf nodu metastazı ile klinik ve patolojik parametreleri karşılaştırmayı amaçladık.

Hastalar ve Yöntem: Çalışmamızda 2010 ile 2020 yılları arasında gastrointestinal sistemde görülen primer ve metastatik malign melanom olgularında bölgesel lenf nodu metastazı ile yaş, cinsiyet, tümör lokalizasyonu, tümör boyutu, ekstraintestinal melanom öyküsü, melanin pigmenti, nötrofil-lenfosit oranı ve tanı sonrası yaşam süreleri arasındaki ilişkiyi değerlendirdik.

Bulgular: Tümör çapı ile bölgesel lenf nodu metastazı arasında istatistiksel bir ilişki vardı $(p=0.000)$. Tümör çapı arttıkça lenf nodu metastaz oranı artmaktaydı. Hayatta kalma ile cinsiyet, tümör lokalizasyonu, uzak metastaz, primer ve metastatik sindirim sistemi melanomları arasında ilişki vardı(tümü $p<0.05$ ). Erkeklerin ve sindirim sisteminden uzak metastaz yapmayan olguların çoğu hayattaydı. Sindirim sistemine melanom metastazı olan hastaların tamamı ile safra kesesi ve ince bağırsak lokalizasyonlu hastaların tamamı hayattaydı. Safra kesesi primer malign melanom tanılı 70 yaşındaki olgumuz literatürde belirleyebildiğimiz en yaşlı hastaydı.

Sonuç: Kutanöz veya kökeni ne olursa olsun, tüm melanomlar, embriyolojik sinir krestinden türetilen hücreler olan melanositlerden kaynaklanır. Malign melanom gastrointestinal sistemde anorektal bölgede daha sık olmak üzere her bölgede primer görülebilir. Son zamanlarda metastatik melanomda, hastalığın metastatik yayılmasını önlemeye yardımcı olmak için immüno-onkolojik ajanların adjuvan tedavide kullanımı söz konusudur. Bu tedaviler sayesinde cerrahi rezeksiyon sonrası metastaz riski taşıyan melanomlu hastaların yarıdan fazlasında rekürrensiz sağ kalım sağlandığı bildirilmektedir. Çok nadir görülmesine rağmen sindirim sistemi biyopsilerinin değerlendirilmesinde primer veya metastatik malign
\end{abstract} melanom olabileceği akılda tutulmalıdır.

Anahtar Kelimeler: Sindirim sistemi, malign melanom, metastaz

\section{Abstract}

Aim: Primary and metastatic digestive system malignant melanomas are extremely rare. In our study, we aimed to compare lymph node metastasis with clinical and pathological parameters in gallbladder stomach, small intestine and anorectal region malignant melanomas.

Patients and Methods: In our study, we evaluated the relationship between regional lymph node metastasis and age, gender, tumor localization, tumor size, extraintestinal melanoma history, melanin pigment, neutrophil-lymphocyte ratio and post-diagnosis life span in primary and metastatic malignant melanoma cases in the gastrointestinal system between 2010 and 2020.

Results: There was a statistical relationship between tumor diameter and regional lymph node metastasis $(p=0.000)$. As the tumor diameter increased, the lymph node metastasis rate increased. There was a relationship between survival and gender, tumor localization, distant metastasis, primary and metastatic digestive system melanoma (all $p<0.05$ ). Most of the men and those who did not metastasize away from the digestive system were alive. All patients with melanoma metastases to the digestive system and all patients with gallbladder and small intestine localization were alive. Our 70 year old patient with gallbladder primary malignant melanoma was the oldest patient we could identify in the literature. Conclusions: Regardless of cutaneous or origin, all melanomas originate from melanocytes, cells derived from embryological nerve crest. Malignant melanoma can be primary in every region, more frequently in the anorectal region in the gastrointestinal tract. Recently, in metastatic melanoma, immuno-oncological agents are used in adjuvant therapy to help prevent metastatic spread of the disease. Thanks to these treatments, it is reported that more than half of patients with melanoma who have the risk of metastasis after surgical resection provide recurrence-free survival. Although it is very rare, it should be kept in mind that there may be primary or metastatic malignant melanoma in the evaluation of digestive system biopsies.

Key words: Digestive system, malignant melanoma, metastasis

Cite this article as: Kulahci $O$, Turan G. Primary and Metastatic Malignant Melanomas of The Digestive System. Selcuk Med J 2020;36(4): 300-306
Disclosure: None of the authors has a financial interest in any of the products, devices, or drugs mentioned in this article. The research was not sponsored by an outside organization. All authors have agreed to allow full access to the primary data and to allow the journal to review the data if requested. 


\section{INTRODUCTION}

Primary and metastatic digestive system malignant melanomas are extremely rare. Malignant melanoma is a tumor that most often originates from the skin, eyes and anorectal region, progresses very aggressively, often metastasizes. Primary mucosal melanoma can appear anywhere within the mucous membrane of the gastrointestinal tract. The most common anorectal (53.6\%), oropharyngeal (32.8\%), esophagus (5.9\%), stomach $(2.7 \%)$, small intestines $(2.3 \%)$, gallbladder $(1.4 \%)$ and in the large intestine $(0.9 \%)(1)$. There are various discussions about whether malignant melanomas in the digestive system are primary or metastatic, and from which cells they originate. On the other hand, malignant melanoma is stated in various studies that it metastasizes $2-4 \%$ to the gastrointestinal tract (2). Metastasis to the gastrointestinal tract is most common in the small intestine (35-65\%), colon (5-9\%) and stomach (5-7\%). After the report of malignant melanoma arising from the gallbladder epithelium in 1907, studies on the malignant melanoma of the gastrointestinal tract increased (3). Lymph node metastasis is one of the important factors determining the prognosis of malignant melanoma (4). In recent years, successful results have been achieved in the treatment of malignant melanoma. Accurate diagnosis is vital in places where it is rarely seen, such as the digestive system. In our study, we wanted to evaluate the relationship between regional lymph node metastasis and age, gender, tumor localization, tumor size, extraintestinal melanoma history, melanin pigment, neutrophil-lymphocyte ratio (NLR) and post-diagnosis life span in primary and metastatic malignant melanoma cases. We aimed to review the literature with the origin of the cells it originated from.

\section{PATIENTS AND METHODS}

This retrospective study included 20 cases diagnosed with malignant melanoma in the organs of the gastrointestinal tract in Adana City Education and Research Hospital between January 2010 and January 2020. Health Sciences University Adana City Education and Research Hospital Ethics Committee approval was obtained (617 decision number and 04.12.2019). Only cases diagnosed with malignant melanoma in the organs of the gastrointestinal tract were included in the study. All our patients underwent surgical resection and regional lymph node dissection. The patients were evaluated together with regional lymph node metastasis, age, gender, tumor localization, tumor size, extraintestinal melanoma history, melanin pigment, preoperative NLR and post-diagnosis life span. Tumor localization was grouped as gallbladder, stomach, small intestine and anorectal region. Tumor size was evaluated as $2 \mathrm{~cm}$ below and $2.1 \mathrm{~cm}$ above. Regional lymph node metastasis, extraintestinal melanoma history, melanin pigment were divided into two groups as positive and negative. The blood values of the patients from the preoperative peripheral vein were analyzed with the Beckman Coulter DXH-800 (Beckman Coulter Eurocenter, Nyon, Switzerland) device, and neutrophil and lymphocyte counts were determined. The neutrophil count was divided by the lymphocyte count and the NLR value was calculated. Regional lymph node metastasis and life time after diagnosis and age, gender, tumor localization, tumor size, extraintestinal melanoma history, melanin pigment and NLR were statistically compared. The cells from which malignant melanoma originated in the digestive system were evaluated by reviewing the literature.

\section{Statistical analysis}

Statistical analysis of the data obtained in the present study was performed using SPSS 19 software package (SPSS Inc, Chicago, Illinois, USA). Categorical variables such as tumor size, tumor localization, distant metastasis, extraintestinal melanoma history, melanin pigment, and regional lymph node metastasis are summarized as number (n) and percentage (\%). Descriptive statistics related to continuous variable, age variable and NLR are summarized as mean \pm standard deviation. Chisquare test was used for analysis of the categorical variables. The statistically significance level was accepted as $p<0.05$ value.

\section{RESULTS}

The mean age of the patients was $61.40 \pm 12.334$. The average of NLR was $2.61 \pm 1.598 .60 \%$ of the cases were male and $40 \%$ were female. $70 \%$ of the cases were located anorectal, $20 \%$ small intestine, $5 \%$ stomach and 5\% gallbladder. There was a statistical relationship between tumor diameter and regional lymph node metastasis $(p<0.001)$. As the tumor diameter increased, the lymph node metastasis rate increased. There was no statistical relationship between gender, tumor localization, melanin pigment and regional lymph node metastasis ( $p>0.05)$. The relationship between lymph node metastasis and clinicopathological findings is shown in table 1 . There was no statistical relationship between age and NLR and regional lymph node metastasis ( $p>0.05)$. There 
Table 1. Relationship between lymph node metastasis and clinicopathological findings

\begin{tabular}{|c|c|c|c|}
\hline & $\begin{array}{l}\text { Regional lymph node } \\
\text { metastasis negative } n(\%)\end{array}$ & $\begin{array}{l}\text { Regional lymph node } \\
\text { metastasis positive } n(\%)\end{array}$ & $p$ value \\
\hline Gender & & & 0,69 \\
\hline $\mathrm{F}$ & $2(25)$ & $6(75)$ & \\
\hline M & $4(33,3)$ & $8(66,7)$ & \\
\hline Tumor localization & & & 0,26 \\
\hline GB & $1(100)$ & $0(0)$ & \\
\hline S & $0(0)$ & $1(100)$ & \\
\hline SI & $2(50)$ & $2(50)$ & \\
\hline AR & $3(21,4)$ & $11(78,6)$ & \\
\hline Tumor size (cm) & & & $<0,001$ \\
\hline$\leq 2$ & $5(100)$ & $0(0)$ & \\
\hline$>2,1$ & $1(6,7)$ & $14(93,3)$ & \\
\hline Extraintestinal melanoma & & & 0,329 \\
\hline Negative & $4(25)$ & $12(75)$ & \\
\hline Positive & $2(50)$ & $2(50)$ & \\
\hline Distant metastasis & & & 0,69 \\
\hline Negative & $2(25)$ & $6(75)$ & \\
\hline Positive & $4(33,3)$ & $8(66,7)$ & \\
\hline Melanin pigment & & & 0,919 \\
\hline Negative & $2(28,6)$ & $5(71,4)$ & \\
\hline Positive & $4(30,8)$ & $9(69,2)$ & \\
\hline Survival & & & 0,202 \\
\hline Dead & $2(18,2)$ & $9(81,8)$ & \\
\hline Alive & $4(44,6)$ & $5(55,6)$ & \\
\hline
\end{tabular}

AR: Anorectal region, F: Female, GB:Gallbladder, M:Male, SI:Small intestine, S:Stomach

was a relationship between survival and gender, tumor localization, distant metastasis, primary and metastatic digestive system melanoma ( $p<0.05$ ). The majority of patients who did not perform distant metastases with male sex were alive. All of our cases with melanoma metastasis to the digestive system, gall bladder and small intestine localization were alive. There was no relationship between tumor size and melanin pigment and survival ( $p>0.05)$. The relationship between survival and clinicopathological

Table 2. Relationship between survival and clinicopathological findings

\begin{tabular}{llll}
\hline & Dead $\mathbf{n}(\%)$ & Alive $\mathbf{n}(\%)$ & p value \\
\hline Gender & & & 0,001 \\
F & $8(100)$ & $0(0)$ & \\
M & $3(25)$ & $9(75)$ & 0,037 \\
Tumor localization & & & \\
GB & $0(0)$ & $1(100)$ & \\
S & $1(100)$ & $0(0)$ & \\
SI & $0(0)$ & $4(100)$ & \\
AR & $10(71,4)$ & $4(28,6)$ & 0,436 \\
Tumor size(cm) & $2(40)$ & $3(60)$ & \\
$\quad$ S2 & $9(60)$ & $6(40)$ & 0,013 \\
$\quad$ P2,1 & $11(68,8)$ & $5(31,3)$ & \\
$\quad$ Extraintestinal melanoma & $0(0)$ & $4(100)$ & 0,028 \\
$\quad$ Pogative & $2(25)$ & $6(75)$ & \\
Distant metastasis & $9(75)$ & $3(25)$ & 0,423 \\
$\quad$ Negative & $3(42,9)$ & $4(57,1)$ & \\
$\quad$ Positive & $8(61,5)$ & $5(38,5)$ & \\
Melanin pigment & Negative &
\end{tabular}

AR:Anorectal region, F: Female, GB:Gallbladder, M:Male, SI:Small intestine, S:Stomach 


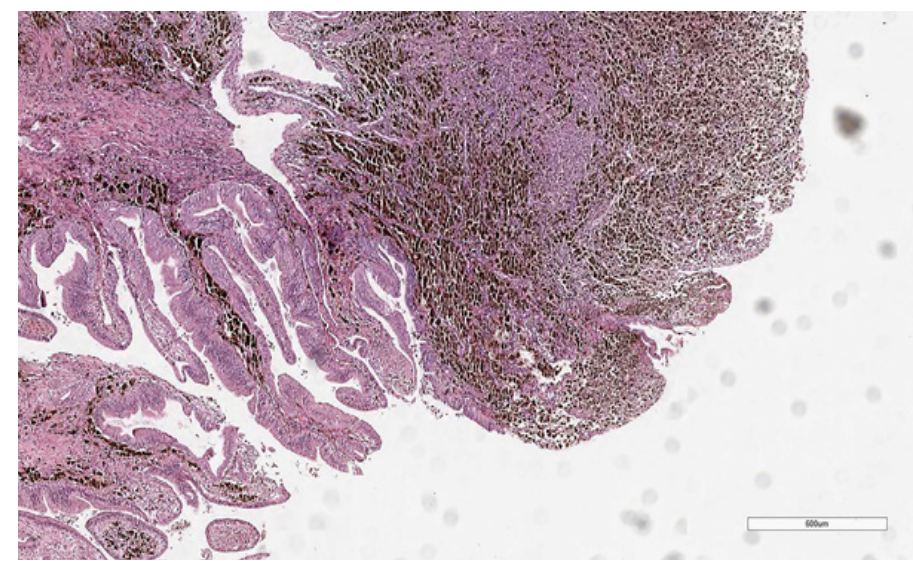

Figure 1. Tumor cells containing melanin pigment adjacent to the gallbladder epithelium (Hematoxylin eosin staining; $x 40$ )

findings is shown in table 2 .

In histomorphological examination, malignant melanoma consists of a nesting pattern of atypical cells with prominent nucleoli, epithelioid or spindle and eosinophilic cytoplasm. It is mostly found in melanin pigment. Histopathological and immunohistochemical images of our gallbladder, small intestine malignant melanoma cases are shown in the figure 1-3.

\section{DISCUSSION}

Regardless of cutaneous or origin, all melanomas originate from melanocytes, cells derived from embryological nerve crest. During fetal development,

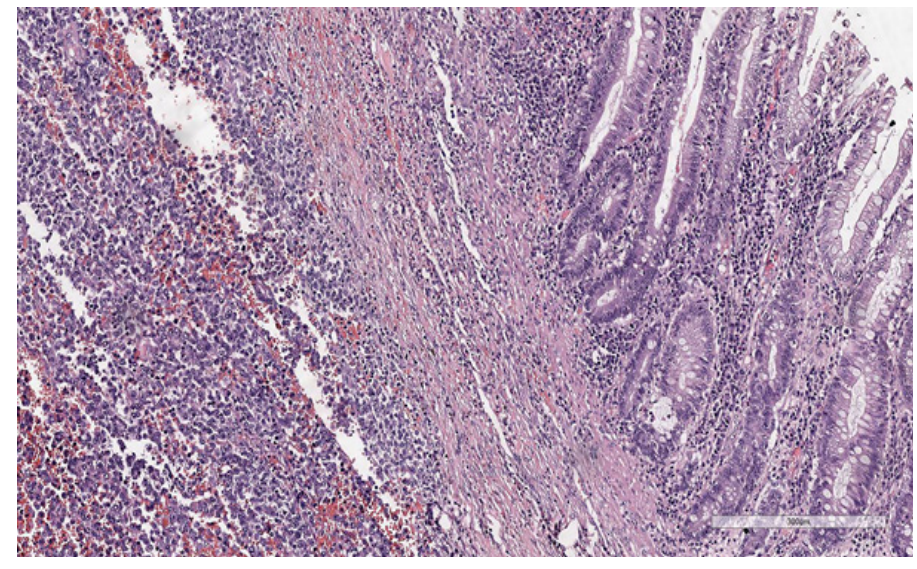

Figure 2. Tumor cells with prominent nucleoli under the epithelium in the small intestine (Hematoxylin eosin staining; $x 100$ )

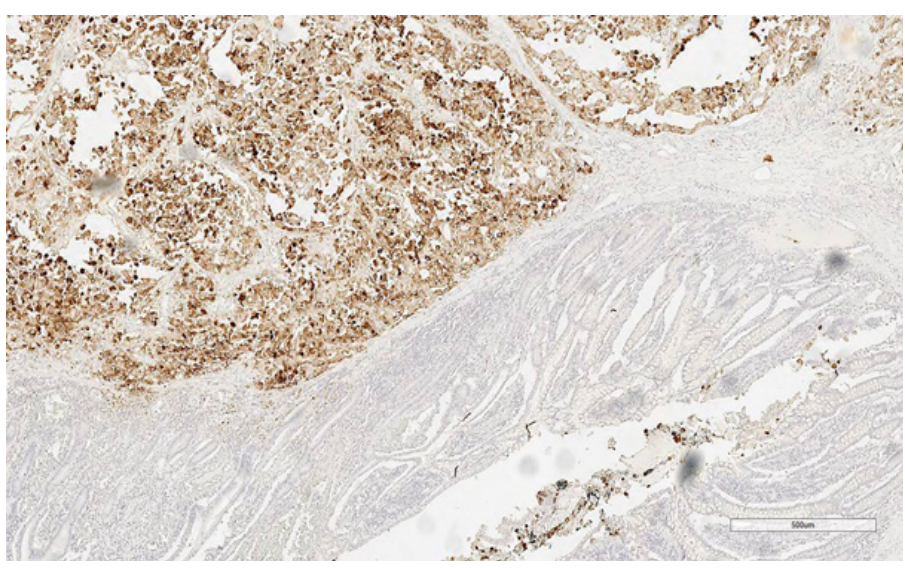

Figure 3. Immunohistochemical HMB45 stained neoplastic cells under the epithelium in the small intestine (HMB45; x40)

these cells migrate to many areas, primarily the skin. However, melanocytes are also found in the eyes and mucosal surfaces. While cutaneous melanomas constitute more than $90 \%$ of all malignant melanomas, $5 \%$ are ocular, $2 \%$ are unknown and $1 \%$ are mucosal melanomas (5). There are various discussions about whether malignant melanomas in the digestive system are primary or metastatic, and from which cells they originate. Some scientists claim that all gallbladder malignant melanomas are metastastic. Scientists investigating that there is primary malignant melanoma in the gallbladder have shown melanocytes in the gallbladder with normal and malignancy (6). In the literature, less than 40 cases of primary gallbladder malignant melanoma have been reported worldwide with our case (7). Our patient was a 70-year-old gallbladder primary malignant melanoma when diagnosed. When we scan the literature, our case was the oldest patient determined at the time of diagnosis. Our case with primary gallbladder malignant melanoma has been followed for 62 months. The patient is alive and his follow-up and treatment continues.

Since there is no melanocyte in the stomach, it has been suggested that gastric melanoma occurs as a result of ectopic migration of melanocyte precursors or differentiation of APUD cells (amine precursor uptake and decarboxylation cells) to melanocytes (8). Primary malignant melanoma of the stomach is extremely rare. When our case is added, there are 21 primary gastric malignant melanoma cases published in the literature to date (9). Our case was the only case 
when we searched the literature for the presence of tubular adenoma in the colon that was accompanied by primary malignant melanoma in the stomach. While the average overall survival associated with primary malignant melanoma of the gastrointestinal tract is reported to be 17 months, this period is only 5 months in the primary malignant melanoma of the stomach (1). He died 4 months after diagnosis in our case.

While malignant melanoma can metastasize anywhere from the mouth to the anus in the gastrointestinal tract, jejunum and ileum are most frequently involved (10). Some authors previously thought that cancer cells in malignant melanoma originate from neuroblastic Schwann cells of the intestinal autonomic nervous system (11). Later, some scientists claim that primary intestinal malignant melanomas develop from melanoblastic neural crest cells migrating from the omphalomesenteric channel to the distal ileum, while others claim that neoplasia develops by taking an enteric non-cutaneous neuroendocrine tissue in the form of decarboxylase (12). While the first hypothesis explains the presence of melanomas in the ileum, the second explains the non-ileum intestinal melanomas (13). In addition, another theory claims that small intestine malignant melanoma is not a separate clinical tumor, but secondary deposits to regressed primary cutaneous malignant melanoma (14). When we searched the literature, we detected 34 primary small bowel malignant melanoma cases reported (15). Blecker et al. determined the following criteria for the diagnosis of primary malignant melanoma of the small intestine. Single mucosal solitary tumor in the intestinal mucosa, the presence of other intramucosal melanocytic lesions in the intestinal epithelium around the tumor, and the absence of skin or mucosal malignant melanoma or other atypical melanocytic skin lesions such as dysplastic nevus (10). The differential diagnosis of primary and secondary malignant melanoma of the small intestine is important for prognosis. It has been suggested that primary intestinal melanomas grow faster and aggressive than metastatic melanomas because of their rich lymphovascular structure in the intestinal mucosa (16). Although metastases to the small intestine in our 4 cases, they are still alive for 20 to 48 months. Two of the cases of metastasis to the small intestine were patients with scalp, one lip and one soles with a diagnosis of malignant melanoma. Malignant melanoma metastasis in the small intestine can be diagnosed by causing intussusception and bowel obstruction. The places where intussusception is most common in adults are the small intestine, ileocecal region and colon. Some researchers have claimed that malignant melanoma is the most common metastatic tumor that causes intussusception (17). Small bowel melanomas sometimes cause solid mass while sometimes causing intussusception. One of our cases was operated 4 years after the diagnosis of malignant melanoma on the lip causing ileo-colic intussusception. Diagnosis can be difficult when tumor cells are amelanocytic. Malignant melanoma should definitely be considered in the differential diagnosis.

Anorectal malignant melanomas are extremely rare and aggressive tumors. It constitutes $0.5-4 \%$ of anorectal malignant tumors and less than $1 \%$ of all malignant melanomas. Melanocytes can be found in the anal squamous region, sometimes in the anal transitional region, but never in the colorectal region. These potential cells pass through the umbilicalmesenteric canal and then transform into special cells that undergo neoplastic transformation. Mostanorectal melanoma arise from the dentate line and $65 \%$ are located in the anal canal (5). Approximately $20-30 \%$ of anorectal malignant melanomas are amelanocytic and may endoscopically resemble benign polypoid lesions (18). One of our cases was diagnosed as malignant melanoma after biopsy with the diagnosis of polyp and the other with hemorrhoids. Our 14 cases of primary anorectal malignant melanoma have been followed up for 65 months and 4 are still alive.

When the National Cancer Institute of Naples examined 1684 patients diagnosed with cutaneous melanoma, it detected metastases in the gastrointestinal tract in $1.7 \%$ of them (19). In autopsies of patients who died with primary cutaneous melanoma, $60 \%$ malignant melanoma metastasis was found in the gastrointestinal tract (20). It is known that spontaneous regression of melanoma in primary skin occurs from time to time. This may explain the absence of any focus on the skin in some metastatic melanoma. The TNM staging system, which includes tumor size, lymph node metastasis and distant metastasis, is used for many malignant neoplasias. Cutaneous melanoma staging is based on primary tumor thickness, ulceration, lymph node, and distant metastases (21). In our study, as the tumor size increased, lymph node metastasis was consistent with the findings of the literature, as in cutaneous melanoma. While Aoyama et al.(22) stated that high NLR helps in determining lymph node metastasis in endometrial cancers, Bulgurcu et al.(23) have not 
found a relationship between lymph node metastasis and NLR in larynx squamous cell carcinoma. In our study, we did not determine a relationship between NLR and lymph node metastasis.

For the diagnosis of primary gallbladder, stomach, small intestine and anorectal malignant melanoma, the patient should be investigated multisystemically, especially the skin and eyes, and no malignant melanoma in another area. Clinical complaints and radiological findings of the patient in the digestive system are not specific for the diagnosis of malignant melanoma. Histopathological examination is the gold standard for definitive diagnosis. The presence of atypical cells with melanin, prominent nucleolus, nesting pattern, is valuable to suspect malignant melanoma. But melanin may not always be available. With the help of immunohistochemical staining such as S100, HMB45 (Human Melanoma Black), MART1 (Melanoma Antigen Recognized by T cells 1). Our gallbladder, stomach, small intestine and anorectal malignant melanoma cases showed immunohistochemical expression of S100, HMB45 and MART1. Recently, in metastatic melanoma, immuno-oncological agents are used in adjuvant therapy to help prevent metastatic spread of the disease. Thanks to these treatments, it is reported that more than half of patients with melanoma who have the risk of metastasis after surgical resection provide recurrence-free survival (24). In the treatment of malignant melanoma and some other tumors, the use of a number of immunomodulatory agents targeting immune system control points such as Cytotoxic T-lymphocyte antigen 4 (CTLA-4), programmed death-1 (PD-1) or ligand (PD-L1) is promising for the treatment (25).Although it is very rare, it should be kept in mind that there may be primary or metastatic malignant melanoma in the evaluation of digestive system biopsies.

Conflict of interest: Authors declare that there is no conflict of interest between the authors of the article.

Financial conflict of interest: Authors declare that they did not receive any financial support in this study.

Address correspondence to: Ozgur Kulahci, University of Health Sciences, Adana City Education and Research Hospital, Department of Pathology, Adana, Turkey

Tel: +90-322-455-9000

e-mail: ozgurkulahci@hotmail.com

\section{REFERENCES}

1. Cheung MC, Perez EA, Molina MA, et al. Defining the role of surgery for primary gastrointestinal tract melanoma. $\mathrm{J}$ Gastrointest Surg 2008;12:731-8.

2. Reintgen DS, Thompson W, Garbutt J, et al. Radiologic, endoscopic, and surgical considerations of melanoma metastatic to the gastrointestinal tract. Surgery 1984;95(6):635-9.

3. Jones $\mathrm{CH}$. Malignant melanoma of the gall-bladder. The Journal of Pathology and Bacteriology 1961;81:423-30.

4. Balch CM, Soong SJ, Gershenwald JE, et al. Prognostic factors analysis of 17,600 melanoma patients: Validation of the American Joint Committee on Cancer melanoma staging system. J Clin Oncol 2001;19:3622-34.

5. Row D, Weiser MR. Anorectal melanoma. Clin Colon Rectal Surg 2009;22(2):120-6.

6. Ricci R, Maggiano N, Martini $M$, et al. Primary malignant melanoma of the gallbladder in dysplastic naevus syndrome. Virchows Arch 2001;438(2):159-65.

7. Virgilio E, Scorsi A, Amodio PM, et al. Primary malignant melanoma of the gallbladder: An outstandingly rare tumor. Clin Exp Med 2016;16(3):479-80.

8. Krausz MM, Ariel I, Behar AJ. Primary malignant melanoma of the small intestine and the APUD cell concept. J Surg Oncol 1978;10(4):283-8.

9. Wang L, Zong L, Nakazato $\mathrm{H}$, et al. Primary advanced esophago-gastric melanoma: $\mathrm{A}$ rare case. World $\mathrm{J}$ Gastroenterol 2016; 22(11): 3296-301.

10. Blecker D, Abraham S, Furth EE, et al. Melanoma in the gastrointestinal tract. Am J Gastroenterol 1999;94(12):342733.

11. Mishima Y. Melanocytic and nevocytic malignant melanomas. Cellular and subcellular differentiation. Cancer 1967; 20(5):632-49.

12. Amar A, Jougon J, Edouard A, et al. Primary malignant melanoma of the small intestine. Gastroenterol Clin Biol 1992;16(4):365-7.

13. Manouras A, Genetzakis M, Lagoudianakis E, et al. Malignant gastrointestinal melanomas of unknown origin: Should it be considered primary? World J Gastroenterol 2007;13(29):4027-9.

14. Schuchter LM, Green R, Fraker D. Primary and metastatic diseases in malignant melanoma of the gastrointestinal tract. Curr Opin Oncol 2000;12(2):181-5.

15. Hadjinicolaou AV, Hadjittofi C, Athanasopoulos PG, et al. Primary small bowel melanomas: Fact or myth? Ann Transl Med 2016;4(6):113.

16. Liang KV, Sanderson SO, Nowakowski GS, et al. Metastatic malignant melanoma of the gastrointestinal tract. Mayo Clin Proc 2006;81(4):511-6.

17. Slaby J, Suri U. Metastatic melanoma with multiple small bowel intussusceptions. Clin Nucl Med 2009;34(7):483-5.

18. Belli F, Gallino GF, Lo Vullo S, et al. Melanoma of the anorectal region: The experience of the National Cancer Institute of Milano. Eur J Surg Oncol 2009;35(7):757-62.

19. Marone U, Caracò C, Losito S, et al. Laparoscopic cholecystectomy for melanoma metastatic to the gallbladder: Is it an adequate surgical procedure? Report of a case and review of the literature. World J Surg Oncol 2007;5:141.

20. Patel JK, Didolkar MS, Pickren JW, et al. Metastatic pattern of malignant melanoma. A study of 216 autopsy cases. Am J Surg 1978;135(6):807-10.

21. Balch CM, Soong SJ, Atkins MB, et al. An evidence-based staging system for cutaneous melanoma. CA Cancer J Clin 
2004;54(3):131-49.

22. Aoyama T, Takano M, Miyamoto $M$, et al. Pretreatment neutrophil-to-lymphocyte ratio was a predictor of lymph node metastasis in endometrial cancer patients. Oncology 2019;96(5):259-67.

23. Bulgurcu S, Arslan IB, Dikilitaş B, et al. Neutrophil to lymphocyte ratio and platelet to lymphocyte ratio in malignant and precancerous laryngeal lesions. Kulak Burun Bogaz Ihtis Derg 2017;27(3):122-7.
24. Grossmann KF, Margolin K. Long-term survival as a treatment benchmark in melanoma: Latest results and clinical implications. Ther Adv Med Oncol 2015;7(3):181-91.

25. Saman MV, Carmen G, Ignacio D. Biomarkers of response to PD-1/PD-L1 inhibition. Crit Rev Oncol Hematol 2017;116:11624. 